\title{
右胸腔を占拠し CA19-9 の異常高值を呈した 巨大縦隔成熟型奇形腫の一治験例
}

四方 裕夫，松原 純一，土島 秀次，塚 正彦*

要 旨

12歳，女性．発熱・胸痛・咳嗽を主訴として近医を受診，右胸腔に巨大な腫瘤を指摘された。胸部 MRI, 胸部 CT, 血液生化学的諸検査などを施行した. CA19-9 が異常高值を呈し, 右胸腔をほとんど占 拠する巨大な腫瘤で, 縱隔左偏位, 拘束性肺障害, 脊柱側弯を認めた。原発部位不明の奇形腫を考慮し た．縦隔内血管への浸潤・癒着が不明なため胸骨正中切開としたが，腫瘤の摘出が困難で，乳房下皮膚 切開, 第7肋間開胸を追加した. 右肺下葉は後下方に圧排, 中葉は腫瘤と完全に分離できず含気も全く認

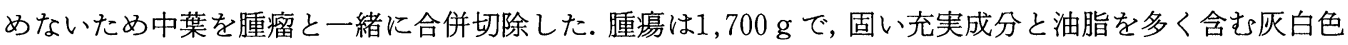
液体成分より成り, 病理診断は縱隔由来の成熟奇形腫であった. CA19-9 は術後経時的に著明に減少し た. 術後の肺血流シンチでは右肺上葉の血流はそしく，下葉の血流は洼とんど見られなかった．術後経 過は順調で術後30日目に退院した。

索引用語：縱隔腫瘍, 成熟型奇形腫, 腫場マーカー, CA19-9

mediastinal tumor, mature teratoma, tumor marker, CA19-9

はじめに

縦隔成熟奇形腫は比較的頻度の高い腫瘍であ るが，多くは無症状であり，胸部単純X線写真 で指摘された時点で巨大な腫瘤となっているこ とがある.このような巨大化した縦隔腫瘍は周 囲組織（肺・心臟・脊柱）の圧排や穿孔・穿破 を来たし症状発現に至る事がある。感冒様症状 で受診し，胸部単純 $\mathrm{X}$ 線写真で縦隔腫瘤に気付 かれた12歳女児の症例に打いて, 術前の血中 CA19-9 值が異常高值を示し, 腫瘍摘出後には 血中 CA19-9 值が著減した巨大成熟型奇形腫を 経験したので，文献的考察を加えて報告する。

金沢医科大学 胸部心臓血管外科学講座

*同 病理学 II 講座

原稿受付 1999年11月29日

原稿採択 2000 年 5 月 1 日
症例

症 例：12歳女児.

主 訴：咳嗽, 発熱, 胸痛.

既往歴：生下時および本疾患時なで特記すべ き事項なし。

家族歴：特記すべき事項なし.

現病歴：1999年 7 月 2 日 $38.1^{\circ} \mathrm{C}$ の発熱あり. 翌 7 月 3 日右胸痛自覚. 7 月 5 日咳嗽出現し, 近医受診. 近医での胸部単純X線写真 (Fig. 1) で右肺に巨大な腫瘤を指摘され, 同医院でMRI (Fig. 2)が施行された. 近医より本院小児外科 に精査, 加療目的のため紹介入院となった.

入院時現症：身長 $155 \mathrm{~cm}$, 体重 $35.5 \mathrm{~kg}, \mathrm{BSA}$ $1.268 \mathrm{~m}^{2}$, 血圧 $120 / 68 \mathrm{Hg}$, 脈拍 $78 /$ 分・整, 呼 吸数 $18 /$ 分，体格・栄養状態は良好で，口唇拉よ び眼瞼結膜に貧血黄疸を認めなかった。体格は 軽度の側弯を示し, 顔貌は正常. 意識状態は清 明であった。右胸部にほとんど肺胞音を聴取で 

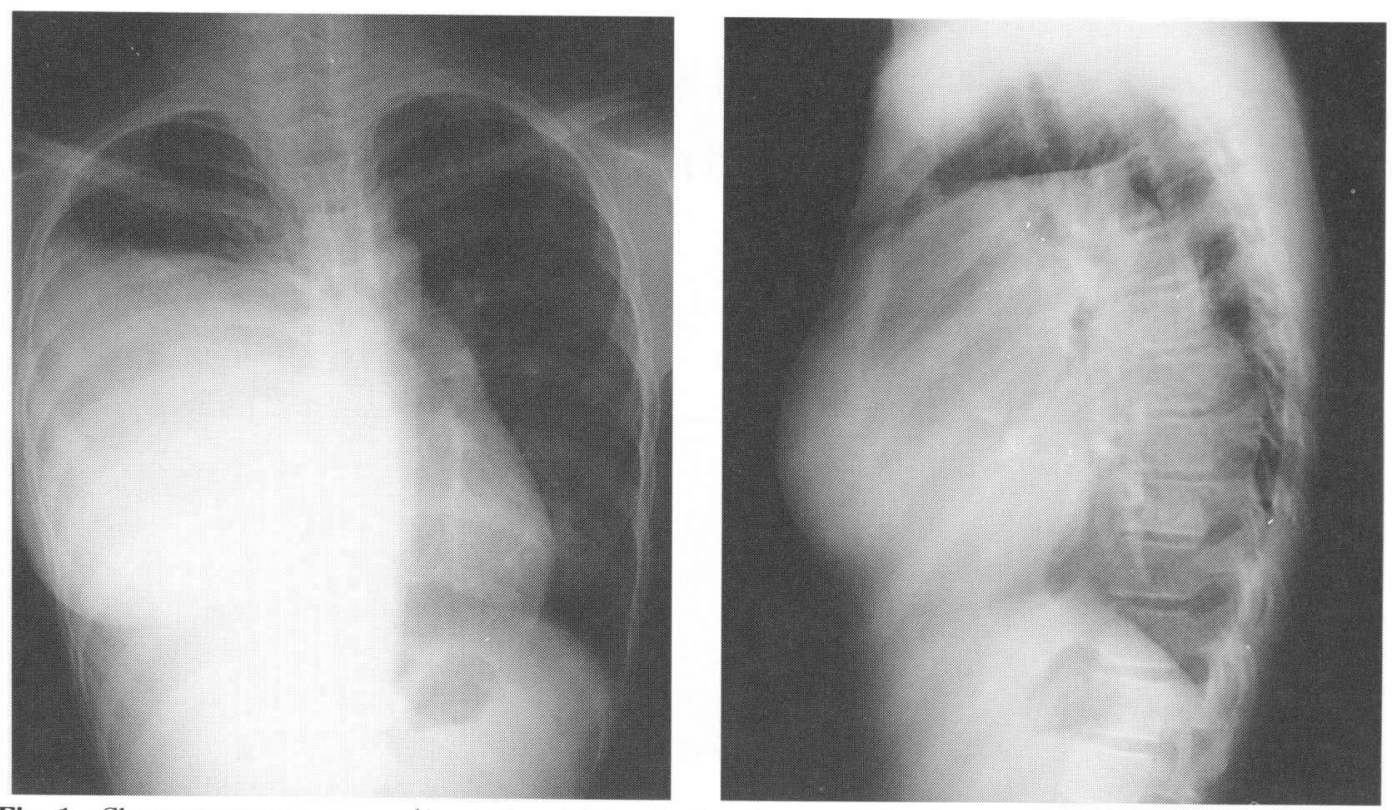

Fig. 1 Chest roentgenograms (frontal and lateral views) revealed a huge mass on the right side of the chest. The right middle and lower lobe are compressed by the mass.

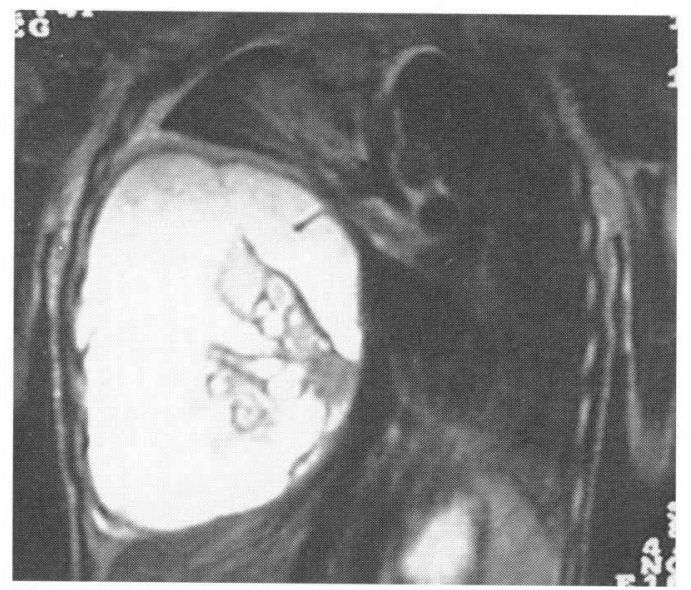

Fig. 2 A T1-weighted MR image showed a highsignal-intensity area that corresponds to the fatty or cheesy tissue. The mass compartmentalized the fluid and fatcontaining area. The right upper lobe was located on the ceiling of the right chest.

きず, 左胸部は正常音を聴取した. 鼠径部, 腋窩, 鎖骨上窩には腫大したリンパ節を認めなかった. 血液生化学的検查は (Table 1) に示した. 腫瘍マーカーは血清中の CA19-9:3,405 (正 常 <37) U/ml, CA602：427 (正常<63) U/ $\mathrm{m} l, \mathrm{CA} 546: 161.2$ (正常 $<12$ ) $\mathrm{U} / \mathrm{m} l$ などが異

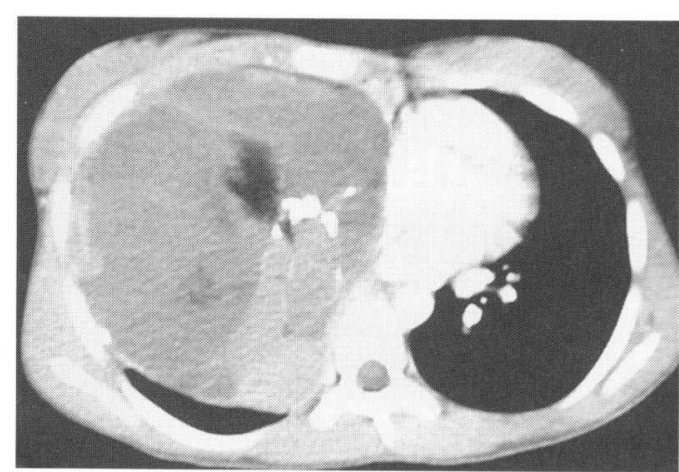

Fig. 3 A contrast-enhanced CT scan revealed a huge heterogeneous mass which consisted of flocculent calcification, a fatcontaining area and a cystic area. The mass com pressed the heart towards the left chest.

常高值を示した。

胸部 CT を Fig. 3 に示す. 右肺上葉と中葉の 一部を除き，巨大な腫瘤によって右胸腔は占拠 され, 内部構造は大部分が水に近い低密度領域 で，一部石灰化成分之脂肪密度成分を含んでい た. 腫瘤は奇形腫の可能性が高く, 発生部位は 不明であった。

胸部 MRI Fig. 2 に示す. 胸部 CT 所見と 
Table 1 Laboratory data on admission

\begin{tabular}{lclr}
\hline RBC & $4.46 \times 10^{6} / \mu l$ & LDH & $415 \mathrm{U} / l$ \\
$\mathrm{Hb}$ & $12.2 \mathrm{~g} / \mathrm{d} l$ & AST & $20 \mathrm{U} / l$ \\
Hct & $38.3 \%$ & ALT & $7 \mathrm{U} / l$ \\
MCV & $85.9 \mathrm{fl}$ & $\gamma-\mathrm{GTP}$ & $10 \mathrm{U} / l$ \\
WBC & $9.03 \times 10^{3} / \mu l$ & ALP & $525 \mathrm{U} / l$ \\
Plts & $480 \times 10^{3} / \mu l$ & CPK & $74 \mathrm{U} / l$ \\
ESR & $35 / 70 \mathrm{~mm}$ & Amylase & $104 \mathrm{U} / l$ \\
CRP & $2.3 \mathrm{mg} / \mathrm{d} l$ & T Chol & $166 \mathrm{mg} / \mathrm{d} l$ \\
$\mathrm{Na}$ & $139 \mathrm{mEq} / l$ & TG & $57 \mathrm{mg} / \mathrm{d} l$ \\
$\mathrm{~K}$ & $3.9 \mathrm{mEq} / l$ & UA & $3.5 \mathrm{mg} / \mathrm{d} l$ \\
$\mathrm{Cl}$ & $97 \mathrm{mEq} / l$ & CPK-MB & $14 \mathrm{U} / l$ \\
Ca & $9.3 \mathrm{mg} / \mathrm{d} l$ & CA19-9 & $3,405 \mathrm{U} / \mathrm{m} l$ \\
$\mathrm{BUN}$ & $10 \mathrm{mg} / \mathrm{d} l$ & CA602 & $427 \mathrm{U} / \mathrm{m} l$ \\
Cr & $0.4 \mathrm{mg} / \mathrm{d} l$ & CA546 & $161.2 \mathrm{U} / \mathrm{m} l$ \\
TP & $7.9 \mathrm{~g} / \mathrm{d} l$ & CEA & $2.2 \mathrm{U} / l$ \\
Alb & $41 \mathrm{~g} / \mathrm{d} l$ & AFP & $1.5 \mathrm{U} / l$ \\
Glucose & $98 \mathrm{mg} / \mathrm{d} l$ & NSE & $7.1 \mathrm{ng} / \mathrm{m} l$ \\
T Bil & $0.5 \mathrm{mg} / \mathrm{d} l$ & Ferritin & $142 \mathrm{ng} / \mathrm{m} l$ \\
D Bil & $0.1 \mathrm{mg} / \mathrm{d} l$ & & \\
\hline
\end{tabular}

同じく液体，脂肪，石灰化，出血成分などが混 在し, 右肺動脈は肺動脈上幹のみが描出され, 中下葉の肺動脈幹である葉間肺動脈とそれ以下 は描出されなかった。 上大静脈は左に圧排され ていたが，閉塞はなかった。 MRangiogram で は feeding arteryを同定できなかった。

${ }^{67} \mathrm{Ga}$ 腫瘍シンチグラムでは異常な集積を認 めず， ${ }^{99 \mathrm{~m}} \mathrm{Tc}$ - HMDP 骨シンチグラムでは骨へ の直接浸潤所見ならびに血行性転移所見とも認 めなかった.

また心ェコーでは腫瘍による圧排偏位はある ものの弁の閉鎖不全，心房 - 心室の拡張不全， 収縮不全などは認めず心機能は正常に保たれて いた.

以上の所見を総合的に考慮し，臨床的診断と して原発部位は不明だが奇形腫を考光手術を行 った.

手術所見（Fig. 4）：右胸腔を汪とんど占拠す る巨大な腫瘍 $(15 \times 15 \times 7.5 \mathrm{~cm})$ のため通常の 肋間開胸では摘出が困難と考光，また縦隔内主 要血管系への癒着または浸潤を考慮し胸骨正中 切開法とした. 腫瘍は被膜に覆われ，縦隔特に 上大静脈への強固な癒着を認めたが剥離可能で あった．腫瘍が大きく胸骨縦切開のみでは摘出

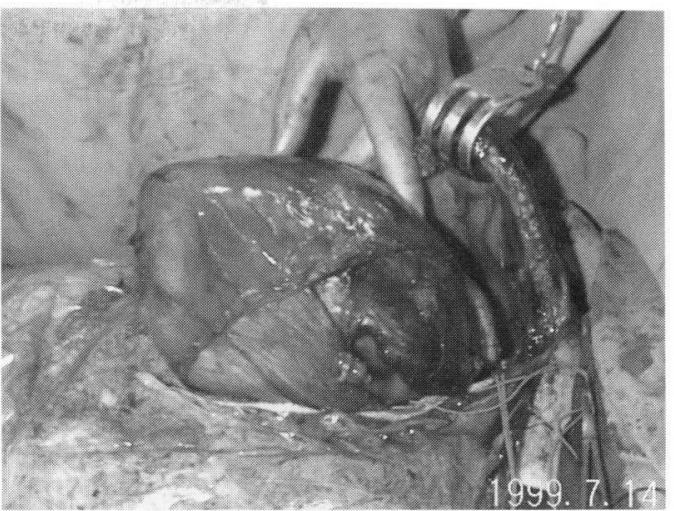

Fig. 4 The operative findings showed a huge mass standing out from the chest. The upper chest wall was lifted upwards with Kent's extension retractor and the operator's hand.

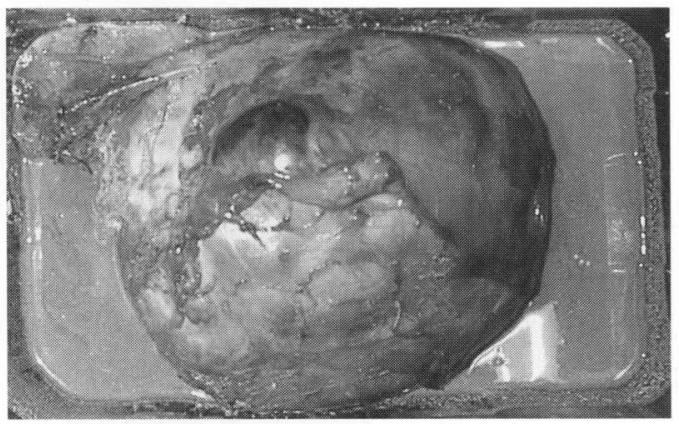

Fig. 5 This shows the macroscopic appearance of the resected tumor. A cheesy fluid flowed out from the teratoma when the tumor was removed from the right chest. Tumor was well-encapsulated near the part of the lung. The cystic compornent of the tumor contained hair, debris and bone.

でさないため，右乳房下皮膚切開・右第 7 肋間 開胸を追加した。腫瘍を挙上すると右肺下葉が 後方に存在し，無気肺であったが加圧したとこ ろ膨張を認めた。右中葉は腫瘍との癒着が著し く含気を全く認めず，再膨張が期待できないと 判断し合併切除した。摘出腫瘍をFig. 5 に示 す. 総重量は $1,700 \mathrm{~g}$ で, 骨様硬組織と内部に毛 髮をはじめとする泥状物をもつ囊胞状病変を有 した．胸腔内に 2 本ドレーンを留置し閉胸した. 術中血行・血液ガスに問題なく, 術中出血量 470 $\mathrm{m} l$, 手術時間 5 時間 40 分で手術を終了した。組 


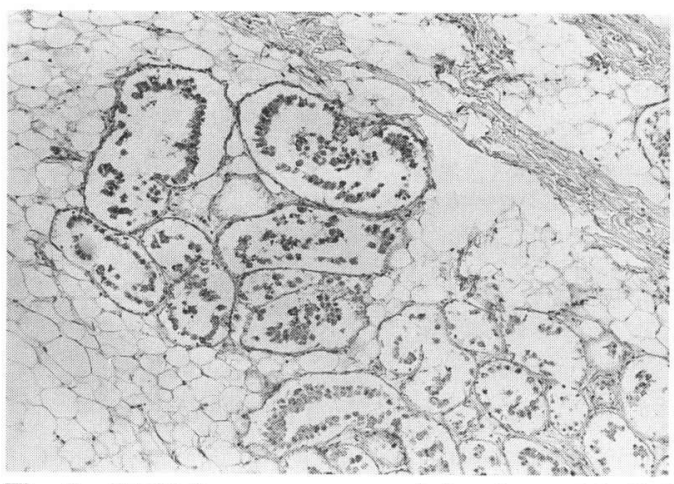

Fig. 6 CA19-9 was expressed in the epithelial cells of sweat gland-like structure of the tumor (Immunostain).

\section{$(\mathrm{U} / \mathrm{ml})$}

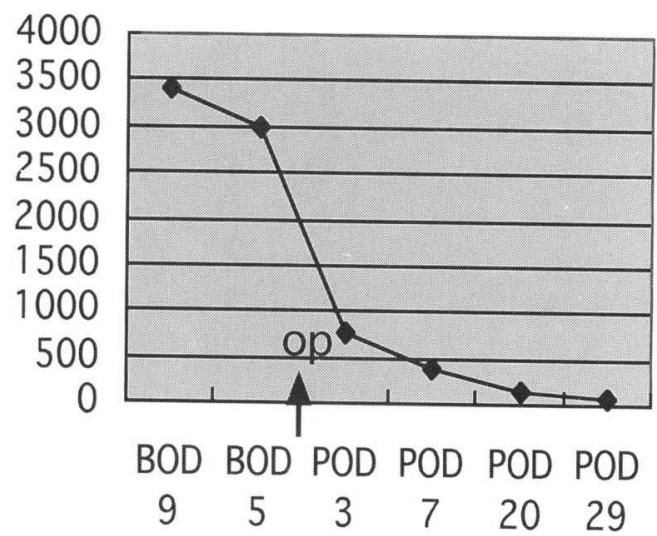

Fig. 7 Change of serum CA19-9 level BOD : before operation day. POD : post operation day.

織学的には皮膚, 神経組織, 成熟脂肪組織を認 めた. CA19-9抗体を用いた免疫組織染色を Fig. 6 に示した. 術後肺血流シンチグラムで右 上葉に血流は認めたが，右下葉には血流は洼々 んど認められなかった。 また術前異常高值を示 したCA19-9は術後より経時的に著減していっ た (Fig. 7). 術後経過は順調で, 術後30日目に 退院した.

\section{考察}

胚細胞腫の 1 つである奇形腫はその好発部位 を卵巣, 辠丸, ついで緹隔とし, 和田ら 1 の全国 統計によれば, 縦隔腫瘍の中で奇形腫は胸腺腫
(31.8\%)，神経性腫瘍（18.8\%) に次ぐ頻度で $16.6 \%$ 占め, その奇形腫の $90.6 \%$ が良性で, $9.4 \%$ が悪性であった. 奇形腫, 中でも成熟型奇 形腫は画像骖断上特徵ある所見を示し, Moeller $5^{2)}$ は CT 上の特徵（軟部組織, 液体, 脂 肪, 石灰化の存在）を報告している. 成熟型奇 形腫は時として胸腔内穿破3), 心タンポナー デ4,5), 自然破裂6) するといら報告もある.成熟型 奇形腫に関し, 平田 $5^{7)}$ や西森 ${ }^{8)}$ (被膜の性 状, 囊胞性か充実性か否か, 内部構造の微小な 変化などの画像診断で，9割以上の症例に良性 悪性の鑑別が可能であったとしている．今回我 々の経験した症例は CT 抢よび MRI での画像 で原発部位不明の成熟型奇形腫と考皇たが，悪 性腫瘍の可能性を否定するには至らなかった。 腫瘍の良悪性鑑別診断に内胸動脈造影が応用さ れることがあるとされるが9,10), 侵襲が大きいと 考光今回の症例では施行しなかった.

一般に悪性縦隔胚細胞性腫瘍は血中 AFP, HCGの上昇が見られることは良く知られてい る. 一方 CA19-9 は1979年 Koprowski ら ${ }^{11)}$ 発見した癌関連糖鎖抗原であり, 消化器癌特に 膵癌, 胆道癌拈よび膵炎で高值を呈するとされ ている. 我々の症例も含めて CA19-9 が異常高 值を示した大きな奇形腫の報告が散見さ $れ^{12-17)}$, それらの中には腫瘍成分に膵の成分を 報告するもの ${ }^{3)}$ や膵酵素が高值を示したもの ${ }^{18)}$, 縦隔奇形腫囊胞の穿破と膵細胞の関与を示唆す るものもある る $^{3,4,6)}$. しかし CA19-9 の免疫染色 を行い, 膵組織では陰性で腸管組織や気管支腺 や気管上皮抒よび気管支円柱上皮が陽性に染ま ったとの報告もあり ${ }^{19,20)}$, 必ずしもこれらの抗 原值が膵組織の存在を示すものではなさそらで ある. 血中括よび囊胞の内容物がCA19-9, CA125, SLX, NSE など様々な腫瘍マーカーの 高值を示す機序は不明であるが211，いずれにせ よ巨大な奇形腫が産生していることには違いな く，汪とんどすべての報告例で腫瘍摘出後に正 常化もしくは著減している. 縦隔奇形腫におい て CA19-9 の值によって悪性奇形腫と良性奇形 腫との鑑別を行らことは今のところ有用ではな いと思われるが, Aoki ら ${ }^{22)}$ はCA19-9 の高值 
を示す膵癌と糖尿病患者の血清をクロマトグラ フィーで分画した興味ある報告を行っている. 即ち膵癌と糖尿病の両者にはCA19-9 エピトー プを表現するムチン分子の大きさに差が認めら れ，その両者を鑑別した報告を行っている．奇 形腫に括ける高 CA19-9 值の意味が膵組織の有 無や，悪性と良性で異なるのか覔かなど，分子 量の高低からの検討が待たれる.ささらに卵巣に 於いて同じ成熟型奇形腫より発生した上皮性腫 瘍 (扁平上皮癌) の診断に関する報告 ${ }^{23)}$ や成熟 型奇形腫の悪性化に関する免疫組織科学的なら

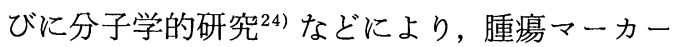
の中で血清 SCC は成熟型奇形腫の扁平上皮癌 化の指標となり得るとされている，縦隔成熟型 奇形腫が指摘された場合には，破裂穿破した報 告や奇形腫が悪性化する頻度は $12 \sim 13 \%$ との報 告25) もあり外科的切除を第一とすべきである.

\section{結語}

12歳の女児の, 胸腔内を占拠した巨大な縦隔 成熟型奇形腫が血中 CA19-9 の異常高值を呈し た 1 切除例を文献的考察を加えて報告した。

\section{文献}

1）和田洋己，寺松 孝：縦隔腫瘍全国統計，日胸 外科会誌 $30 ： 374-379,1982$.

2) Moeller KH, Rosado-de-Christenson, Templeton PA : Mediastinal Mature Teratoma: Imaging Features. A J R $169: 985-990,1997$.

3）藤村重文, 石木幹人, 近藤 丘, 他：腫瘍内に 膵組織を伴った縱隔奇形腫の胸腔内穿孔例. 日 胸 $10: 896-900,1984$.

4）藤野茂樹, 渡辺洋宇, 佐藤日出夫, 他：心タン ポナーデを呈した良性緃隔奇形腫の 1 治験例. 日胸疾会誌 $18: 649-653,1980$.

5）李 民実，李 永浩，生島宏彦，他：心膜を穿 破し心タンポナーデを呈した縦隔奇形腫の 1 切除例. 日胸外会誌 39:1771-1776, 1991.

6) Sasaka K, Kurihara Y, Nakajima Y, et al : Spontaneous rupture: A complication of benign mature teratomas of the mediastinum. A J R 170 : 323-328, 1998.

7）平田賢一, 山本浩史, 佐藤四三, 他: 成人の後 腹膜奇形腫の 1 例. 日臨外医会誌 $43: 451-$ $455,1982$.

8）西森武雄, 大平雅一, 西脇英樹, 他：教室で経 験した後腹膜腫瘍の臨床. 日臨外医会誌 48 ： 80-84, 1987.

9）小川利隆, 山口 豊, 岩井直路, 他: 増大速度
が比較的早く，術前に内胸動脈一肺動脈吻合を 認めた成熟型奇形腫の一切除例. 日胸 47 : 146-150, 1988.

10）田中良明, 佐久間貞行：前縦隔腫瘍の各 $X$ 線診 断法の比較一内胸動脈撮影の役割一. 臨放 14:109-111, 1969.

11) Koprowski H, Steplewski Z, Michell K, et al : Colorectal carcinoma antigen detected by hybridoma antibodies. Somatic Cell Genetics 5: 957-972, 1979.

12）富永幸治, 門倉光隆，斎田清彦，他：感冒様症 状で発見された巨大縦隔奇形腫の 1 治験例. 胸 部外科 $47: 944-947,1994$.

13）脇山英丘，岡田昌義，安宅啓二，他：豪胞状奇 形腫が疑われた前縦隔巨大囊胞の 1 例. 胸部外 科 50：409-412，1997.

14）向井浩文, 内山典明, 中條政敬, 他：血中 CA19 -9, CA125 拈よび胸水中 CA19-9, CA125，ア ミラーゼが高值を示した縦隔原発成熟型奇形 腫の 1 例. 日胸 $53: 628-631,1994$.

15）山本 聡, 赤間史隆, 内川徹也, 他：血中扰上 び腫瘍内 CA19-9 が高值を示した良性縦隔奇 形腫の手術経験. 日胸 $48: 148-146,1989$.

16）中島真太郎，奥道恒夫，木村厚雄，他：CEA 及 びCA19-9 陽性を呈した前縦隔成熟奇形腫の 1 例. 日臨外医会誌 $58: 2831-2835,1997$.

17）福島 剛, 中野詩朗, 米山重人, 他：血清 CEA およびCA19-9 の高值を示した巨大成熟型後 腹膜奇形腫成人例. 日臨外医会誌 $57: 1713^{-}$ 1718, 1996.

18）岩田 勝, 清水康男, 田野正夫, 他：豪胞液の 膵酵素および腫瘍マーカーが異常高値を示し た成熟型奇形腫の 1 例. 日胸 $53: 1033-1038$, 1994.

19）南 寛行, 系柳則昭, 窪田芙佐雄, 他: 血中 CA19-9 が高値を示した縦隔成熟型奇形腫の 1 例. 日胸外会誌 $42: 2139-2143,1994$.

20）藤原清宏, 中野 昇, 甲斐康之, 他：襄胞内 CA19-9, CEA が高值を示した縦隔成熟奇形腫 の 1 例. 日胸 $53: 915-919,1994$.

21）大野 康, 澤 祥幸, 横山美, 他：豪胞液中 の各種腫瘍マーカーが高值を示した成熟縦隔 奇形腫の 1 例. 日胸疾会誌 $\mathbf{3 4}: 1359-1363$, 1996.

22) Aoki N, Iio $\mathrm{K}$, Ohno $\mathrm{Y}$ : Evaluation of serum incraese of low molecular weight moieties. J Jpn Cancer Thr 29: 62-72, 1994.

23) Kikkawa F, Nawa A, Takakoshi K, et al : Diagnosis of squamous cell carcinoma arising from mature cystic teratoma of the ovary. Cancer 82 : 2249-2255, 1998.

24) Yoshioka $T$, Tanaka $T$ : Immunohistochemical and molecular studies on malignant transformation in mature cystic teratoma of the ovary. J Obstet Gynaecol Res 24 : 83-90, 1998.

25）吉竹毅：縦隔原発胚細胞性腫瘍. 胸部外科 43 : 582-592, 1990. 


\title{
The case of a mediastinal huge mature teratoma in a 12-year-old girl with an extremely increased serum CA19-9 level
}

\author{
Hiroo Shikata, Junichi Matsubara, Shuji Tsuchishima, Masahiko Tsuka*
}

The Department of Thoracic and Cardiovascular Surgery, Kanazawa Medical University Kanazawa, Japan

*The Second Department of Pathology, Kanazawa Medical University, Kanazawa, Japan

A 12-year-old girl was admitted to our hospital with a huge abnormal shadow in her right chest. Her chief complaints were slight chest pain and a cough. A chest X-ray and Chest MRI showed a huge heterogenous mass that occupied almost all of her right chest cavity and measured $15 \times 15 \times 7.5 \mathrm{~cm}$ in size, and was made up of soft tissue, fluid, fat, and calcium.

Although we strongly suspected a mature teratoma, the origin was unknown. Because the serum CA19-9 level was extremely high at 3,405 U/m $l$, normal : $<37 \mathrm{U} / \mathrm{m} l$, we could not completely reject the possibility of a malignant neoplasm in the mass. Therefore we decided to treat her surgically. The mass was too huge to be removed by a median sternotomy incision, so we added a submammary incision. The weight of the removed mass was $1700 \mathrm{~g}$. Pathological findings revealed the mass to be as a mature teratoma without any malignant neoplasm. The extremely high serum CA19-9 level gradually decreased to almost normal levels after the operation. Her postoperative course passed without difficulty and she was able to leave our hospital one month after the operation. 